\title{
Professional Regulation for Australasian Genetic Counselors
}

\author{
Cass Hoskins $^{1}$, Clara Gaff ${ }^{2345}$, Alison McEwen ${ }^{6}$, Ivan Macciocca ${ }^{78}$, Amy Pearn ${ }^{9}$, \\ Carolyn Shalhoub ${ }^{10}$, Hayley Salvemini ${ }^{11}$, Jennifer Berkman ${ }^{12}$, Kate E. Riley ${ }^{1314}$, \\ Rachel Williams ${ }^{1516}$, Michael Milward ${ }^{17}$, Mary-Anne Young ${ }^{18},{ }^{19}$
}

Corresponding author:

Cass Hoskins:

+61423875004

cass.hoskins@petermac.org

\footnotetext{
${ }^{1}$ Parkville Familial Cancer Centre and Genomic Medicine, Peter MacCallum Cancer Center, Melbourne, Australia

${ }^{2}$ Australian Genomics Health Alliance, Melbourne, Australia

${ }^{3}$ University of Melbourne, Melbourne, Australia

${ }^{4}$ Melbourne Genomics Health Alliance, Melbourne, Australia

${ }^{5}$ Walter and Eliza Hall Institute, Melbourne, Australia

${ }^{6}$ Graduate School of Health, University of Technology Sydney, Sydney, Australia

${ }^{7}$ Victorian Clinical Genetics Services, Melbourne, Australia

${ }^{8}$ Murdoch Children's Research Institute, Melbourne, Australia

9 The Gene Council, Perth, Australia

${ }^{10}$ Centre for Clinical Genetics, Sydney Children's Hospital, Sydney, Australia

11 Paediatric and Reproductive Genetics Unit, Women's and Children's Hospital, North Adelaide, Australia

12 Genetic Health Queensland, Royal Brisbane and Women's Hospital, Brisbane, Australia

13 Royal Women's Hospital, Melbourne, Australia

14 Western Health, Melbourne, Australia

15 Prince of Wales Clinical School, University of New South Wales, Sydney, Australia

16 Prince of Wales Hereditary Cancer Centre, Prince of Wales Hospital, Sydney, Australia

17 Tasmanian Clinical Genetics Service, Royal Hobart Hospital, Hobart, Australia

18 Kinghorn Centre for Clinical Genomics, Garvan Institute of Medical Research, Sydney, Australia

19 University of New South Wales, Sydney, Australia
}

H.S. current institutional affiliation: Repromed, Monash IVF Group, Adelaide, Australia 


\begin{abstract}
As a result of the ongoing global expansion of genetic counseling, the need to formalize a system of professional regulation for genetic counselors was identified in Australasia. In June 2017, under the auspices of the Human Genetics Society of Australasia (HGSA) a working party was convened. The purpose of the working party was to provide strategic leadership for the profession of Australasian genetic counselors with a goal to formalize a national regulatory framework for genetic counselors across both Australian and New Zealand jurisdictions. This was ultimately achieved in Australia through full membership with the National Alliance of SelfRegulating Health Professions (NASRHP) whilst the profession of genetic counseling in New Zealand is utilizing this framework to establish their regulation pathway. Regulation has a number of implications for genetic counselors, their employers and the wider community, with the primary purpose of regulation being protection of the public from harm. This paper details the process of formalizing self-regulation for genetic counselors in Australasia, by: defining professional regulation; outlining the purpose of regulation and the status of regulation for genetic counselors in Australasia and internationally, as well as health professionals more broadly; exploring the challenges of establishing regulation in Australasia; and the next steps for regulation in Australasia. Through detailing this process, the intention is to provide a framework to support genetic counseling colleagues internationally as well as other health professions in Australasia to explore and achieve regulation through their respective jurisdiction.
\end{abstract}

KEY WORDS: genetic counseling, regulation, professional development, Australasia, workforce, genetic counselors. 


\section{INTRODUCTION}

Genetic counseling is a relatively new and rapidly evolving professionand the employment of genetic counselors in the United States is projected to grow 27 percent over the next ten years (Careercast, 2018). In 2019, there were approximately 7,000 genetic counselors working across 28 countries (Abacan et al., 2018). There are approximately 480 individuals with a genetic counseling qualification in Australasia (Australia, New Zealand and adjacent islands), 220 working in clinical roles (Nisselle et al., 2019). Comparable to other countries, there has also been expansion into roles that includes management, administration, education, academia, industry, research, as well as advisory and policy roles (Abacan et al., 2018).

Global efforts to regulate the profession of genetic counselors are also taking place. It is imperative that the profession communicate and share experiences of professional regulation to support the ongoing evolution of the profession on a global level, and provide information to other countries who wish to institute a process of formal professional regulation (Yashar and Peterson 2013).

This paper provides an account of the Australasian experience of establishing a nationally recognized professional regulation system, including the challenges encountered. We also consider the future directions of regulation both in Australasia and internationally.

\section{Professional regulation}

"Regulation" involves an intervention that seeks to monitor and control the activities of a profession that are of public or social value (Selznick, 1985). Professional regulation of health professionals "provides an essential foundation for the delivery of high-quality health services" to the public (Carlton, 2005, p.21). 
The primary purpose of regulation is to protect the public from harm by setting standards and systems to ensure health professionals have the required knowledge, training, competency, and conduct to practice appropriately and safely (Braithwaite, Healy, \& Dwan, 2005). Providing the public with a means of identifying competent health professionals strengthens community trust (Radford et al., 2014; Skirton 2013).

A secondary benefit of regulation includes the recognition and further advancement of the health profession with lack of regulation viewed as a barrier to ongoing professionalization (Abacan et al., 2018; Barlow-Stewart et al., 2017; Baty, 2018; Cordier et al., 2012; Radford et al., 2014; Skirton, Kerzin-Storrar, et al., 2013, Ormond et al., 2018).

\section{Forms of Regulation}

Although the terms licensure, registration or accreditation are also used interchangeably and vary in interpretation, broadly there are two institutional forms of regulation (Doyle, 1997).

1. Statutory regulation refers to professions that must be registered with a professional regulatory body by law, e.g. state licensure in the USA.

2. Self-regulation refers to professions that regulate either under a rule issued by a government-appointed regulatory body or under their professional association. However, there are no legal requirements and it may arise through voluntary agreements.

\section{Regulation of genetic counselors internationally}

In many parts of the world, registration bodies and professional societies have adopted

a self regulatory role with only afew countries having National statutory regulation 
(Cordier et al., 2012; Skirton et al., 2013; Abacan et al., 2018). In some countries, self and statutory regulation for genetic counselors co-exist (see Table 1). In these countries, regulation and certification/registration through the appropriate professional society is integral to statutory regulation. Abacan et al. (2018) describe regulation, and the broader, global state of the genetic counseling profession in further detail.

\section{Regulation of health professionals in Australasia}

Australia and NZ have different approaches to regulation of health professionals generally. Currently New Zealand does not have a statutory peak body overseeing regulation of health professions. Instead, health professions submit directly to the New Zealand government's Ministry of Health to be recognized as self regulating under the principles of the Health Practitioners Competence Assurance Act.

In Australia, approximately one quarter of the health professions in Australia are regulated through a statutory process, the National Registration and Accreditation Scheme, administered by the Australian Health Practitioner Regulation Agency (AHPRA). After July 2010, regulation in Australia through the National Registration and Accreditation Scheme was confined to those health professions that were already or partially registered, and inclusion of other health professions has been deferred. This means three quarters of recognized health professions, including genetic counselors, must seek other pathways for regulation (Allied Health Profession Australia, 2012).

The National Alliance of Self-Regulating Health Professions (NASRHP) was formed in 2008 under the auspices of Allied Health Professions Australia, and was supported by seed funding by the Australian Government Department of Health. NASRHP is the national peak body representing self-regulated health professionals in Australia, and 
is a formal, independent body providing a regulatory framework for professions not regulated under the National Registration and Accreditation Scheme. NASRHP member organizations must meet benchmarked standards for self-regulation and accreditation of practitioners

Both forms of regulation facilitate national consistency for health professionals and meet national and jurisdictional regulatory requirements, including the National Registration and Accreditation Scheme (Allied Health Profession Australia, 2012) and National Code of Conduct for healthcare workers (Australian Health Ministers' Advisory Council, 2014).

\section{RECOGNIZING SELF-REGULATION OF GENETIC COUNSELORS IN AUSTRALASIA}

\section{Self-regulation by the professional association}

In the late 1980's the Human Genetics Society of Australasia (HGSA) formally recommended and recognized genetic counselors as a professional group (Sahhar, Young, Sheffield, \& Aitken, 2005). Over the next 30 years, the profession iteratively developed a robust training and certification program for Australian and New Zealand genetic counselors reflecting the social and cultural environment of Australasian genetic counselors (McEwen, Young \& Wake, 2013). The Masters curriculum and the portfolio of work required to achieve certification are described by McEwen, Young and Wake (2013) and defined in the HGSA policy 'Guidelines for Training and Certification in Genetic Counselling' (Human Genetics Society of Australasia 2016).

Australasian genetic counselors currently operate as allied health professionals with specialised education pathway and competencies aligned with international 
competencies in genetics and counseling (Human Genetics Society of Australasia, 2016).

For many years Australasian genetic counselors were self-regulated based on competency and adherence to the Code of Ethics within the HGSA. This was termed 'certification' and involved both theoretical and skill based competencies. Although professionally rigorous, the role and recognition of the training and competencies required to practice as a genetic counselor were not widely recognized outside of the HGSA and by individual employers.

This was despite the Australian Law Reform Commission, in 2003, endorsing examination of options to further the development of genetic counseling as a recognized health profession (Australian Law Reform Commission \& Australian Health Ethics Committee, 2003). This included statutory regulation systems specifically to protect the public from individuals who refer to themselves as genetic counselors although not appropriately trained, qualified or supervised (Australian Law Reform Commission \& Australian Health Ethics Committee, 2003). It was therefore unsurprising that for the last decade, formal regulation was identified as a vital next step for both Australasian genetic counselors and colleagues internationally (BarlowStewart et al., 2017; Sane et al., 2015; Skirton et al. 2013).

\section{Self-regulation under NASRHP}

There is an expectation from the Australasian public that healthcare delivery meets a governed standard. Regulation of health professionals is imperative to achieve this, and with this in mind, a working party, the Professional Issues for Genetic Counseling Working Party, was established in June 2017 and convened by the HGSA. The working party comprised 13 members, 11 genetic counselors (2 PhD, 9 MSc or 
equivalent), 1 genetic counseling masters student and a part time project manager. Ten of the genetic counsellors were long standing members of the profession and had attained HGSA Board Certification. The chairperson was a genetic counselor and the immediate past president of the HGSA. Invitations by the chair for membership were accepted by professionals with experience in the development of the profession, nationally and internationally, as well as the current chairs of the genetic counselors special interest group and the Board of Censors in Genetic Counseling. An expression

of interest process was also held, with members selected to ensure broad representation with respect to geography (from each state in Australia and New Zealand), career stage (student to senior genetic counselors) and work setting (e.g. public and private sector, academia). The purpose of the working party was to provide strategic leadership for the profession of genetic counseling towards achieving professional recognition and pursue membership of NASRHP.

Given the two jurisdictions of Australia and New Zealand, it was determined that the working party would begin by pursuing formal regulation within Australia, to then inform the process in New Zealand.

\section{Meeting NASRHP standards}

NASRHP have 11 evidence-based national standards for self-regulation and accreditation. Some standards, including policies and certification standards, were already in place through the HGSA, in which case they were reviewed and modified. Other standards needed to be modified or developed (see Table 2).

In consultation with NASRHP, the working party identified that successful recognition of genetic counselor self-regulation required changes to the governance of the profession under the HGSA. The most significant change meant distinguishing and 
clarifying the roles of the Australasian Society of Genetic Counsellors (ASGC), a special interest membership group acting as the membership body representing and advocating for Australasian genetic counselors, the Board of Censors in Genetic Counselling, a committee of the HGSA responsible for the education, training and certification of genetic counselors, and an independent Professional Concerns and Complaints Committee (see Figure 1).

The application was submitted to NASRHP in September 2018. The application was reviewed by NASRHP assessors and provisional membership granted in February 2019, with further requirements to be fulfilled for full NASRHP membership. Alongside preparing the application to NASRHP, the HGSA Implementation Committee for Genetic Counsellor Regulation was established and formally convened in February 2019 to implement the changes necessary to meet the 11 NASRHP regulatory standards. Full membership was granted in March 2020, recognizing the HGSA and its Board of Censors for Genetic Counselling as the appropriate body for the regulation of genetic counselors in Australia. At this time, formal implementation began, with transitional provisions in place until March 2023, based on a three year timeframe in line with NASRHP requirements.

\section{Implementation of NASHRP standards}

As part of NASRHP membership, and in line with other registered and regulated health professions, the HGSA now hosts an online register of regulated genetic counselors. The register is publically accessible so that employers and the public can ensure that they are using services from appropriately trained and qualified genetic counselors. In order to appear on the register, Australasian genetic counselors must undertake HGSA Board Certification, and upon completion they must continue to demonstrate 
competency by engaging in a minimum of 25 hours of Continuing Professional Development (CPD) activities annually to maintain their registration. A range of learning activities in the areas of skills and knowledge are required, as detailed in the HGSA CPD policy (Human Genetics Society Australasia, 2019). Genetic counselors who are undergoing the HGSA Board Certification process are listed as provisional on the register.

Clinically practising genetic counselors are required to renew their registration annually by submitting mandatory declarations about their CPD and professional supervision, hours of practice, and professional indemnity insurance. The HGSA Professional Concerns and Complaints Committee has also been formed to independently receive, manage and resolve complaints about genetic counselors. Genetic counselors may have their registration expire or terminate if they do not submit annual registration requirements, or for a breach of the HGSA Code of Ethics or Scope of Practice for Genetic Counselors. Genetic counselors who do not actively participate in the regulatory process are not eligible for inclusion on this register.

The Professional Issues for Genetic Counseling Working Party explored regulation pathways across two distinct jurisdictions, Australia and New Zealand. Having established regulation through NASRHP in Australia, the profession of genetic counseling in New Zealand is utilising this framework whilst identifying and pursuing local pathways for regulation. By electing to first pursue recognition in Australia, and, once established, utilising this framework as the basis for formal recognition in New Zealand, the working party demonstrated the reciprocal benefits of documenting and achieving NASRHP membership. This is particularly relevant for genetic counselors in the Asia Pacific region who have formed a special interest group, The Professional 
Society of Genetic Counselors in Asia as part of the Asia-Pacific Society of Human Genetics (APSHG). Alongside this, a number of countries in the Asia Pacific region are independently navigating self-regulation of genetic counselors within their own countries.

\section{Communication}

Early on, the Professional Issues for Genetic Counseling Working Party identified communication as critical to successfully operationalize and implement NASRHP recognition of self-regulation within the Australasian genetic counseling profession (McEwen, Young \& Wake, 2013). Whilst preparing the application to NASRHP, an extensive communication and consultation program with the HGSA genetic counselors was undertaken including written and video communications, a dedicated email address for regulation-based questions and feedback and question and answer sessions at national conferences to invite feedback and engagement.

The most prevalent concerns raised about the regulation process were from genetic counselors who had not undertaken HGSA certification and were practicing clinically, who were concerned about the perceived impact on their ability to practice. There is ongoing work to ensure the process of HGSA Board Certification, and therefore regulation, becomes more inclusive of the increasingly diverse roles of genetic counsellors. At this time, Australasian genetic counselors who work outside of the established Australasian clinical context although see patients (for example, those working in research) are encouraged to discuss regulation with the HGSA Board of Censors.

Communication also occurred with other various stakeholders including employers in the public and private health sectors and government. Throughout the application to 
NASRHP and subsequent implementation of regulation, communication with employers, government ministers, unions, indemnity insurers, consumer groups, and genetic counselors themselves was prioritised to allow for transparency and feedback. In particular, ongoing communication to health service providers is imperative to ensure awareness of NASRHP regulation and the process of registration of genetic counselors through the HGSA.

Although uptake on the register has been high (over $90 \%$ ), there are a small number of practicing genetic counsellors who have not registered and may have partially or never engaged with the regulatory process. This is a risk that employers need to manage to ensure safe practice.

Socialization via communication of the new regulation protocol and standards has been vital to ensure all stakeholders are aware of the new regulatory framework to ensure the continued practice of competent genetic counselors. Establishing regulation involved a significant cultural change of the profession, including stakeholder adjustment to the introduction of benchmark standards and a new governance system. With the evolution of regulation from a voluntary to a mandated system, the Implementation Committee for Genetic Counseling Regulation continues to facilitate the implementation of the self regulatory process and ongoing socialization and communication of the protocol.

\section{IMPLICATIONS AND FUTURE CHALLENGES}

Self-regulation for genetic counselors through registration with the HGSA currently remains voluntary in Australia and New Zealand. The Implementation Committee for Genetic Counsellor Regulation is continuing to address the wider implications, and seek statutory endorsement for the regulatory process from the New Zealand 
Government and Australian Federal, State, and Territory governments to ensure safe access to genetic counseling services for the public. Throughout this, the profession of genetic counseling in Australia continues to be engaged with advocacy groups such as the Allied Health Professions Australia to ensure representation at a federal level.

\section{Workforce}

The profession continues to explore access to government reimbursement for genetic counseling services in Australasia. There are universal difficulties in remuneration for genetic counseling services, however, regulation can be fundamental in supporting genetic counselors to access reimbursement for their services, as a structure exists that ensures those that are providing genetic counseling are safe and competent practitioners (Sane et al., 2015; Stoll et al., 2018).

It is currently not a requirement for an Australian health practitioner to be statutorily regulated in order to provide a medical service for which the Australian Government will pay a rebate, however, some recognized form of regulation is required to obtain these services. It is therefore possible, that the formalization of self-regulation in Australia may enhance genetic counselors' ability to expand into appropriately funded independent practice, as well as provide credibility for other health professionals and allow for more recognition and better access to Australian Government reimbursement, either through the public funded Medicare system or through private health insurance rebates (Skirton, Cordier, et al., 2013; Collis, Gaff, Wake, \& McEwen, 2018). With the increasing likelihood that genetic counselors will practice outside of public hospital genetics services, this is an important implication to consider. Currently, the Implementation Committee for Genetic Counselling Regulation are exploring funding models and reimbursement services further. 
In the USA, there is an observable trend of licensed genetic counselors expanding out of clinic roles in tertiary hospitals and universities into industry and private practice as a result of increased autonomy (Cohen, Tucker, Delk 2017). It is speculated that licensure has contributed significantly to this movement (Cohen, Tucker, Delk, 2017). A recent bill (H.R. 3235) was submitted to the US House of Representatives, which calls for recognition, by the Centers for Medicare \& Medicaid Services (NSGC, 2019). It is believed that the success of this bill will assist in the recognition of genetic counselors as health practitioners and allow for reimbursement for their services, whilst potentially influencing similar policies in countries around the world, including Australasia.

\section{Title protection}

Whilst recognizing the benefits of regulation of the genetic counseling profession in Australasia, one gap in particular remains. Although self-regulation recognized by NASRHP affords a certain level of protection of the genetic counselor title through the provision of a publicly available register listing regulated health professionals, this system does not provide legal protection of a title, therefore there is no prohibition on any person in Australia, regardless of qualifications claiming to offer genetic counseling services. As the profession of genetic counseling was unable to obtain statutory regulation through an alternate pathway, it is currently not illegal for individuals who are not registered to use the title 'genetic counselor'. Consequently, it is challenging to effectively respond to incidences such as an Australian beautician allegedly providing medical advice under the auspices of a genetic counsellor title, despite never undergoing tertiary genetic counselling training (Vlasic, 2016). Statutory protection of the title "genetic counselor" and restricting practice of the profession to 
those individuals who are appropriately trained and regulated confers a greater protection for the public from the potential harms of receiving a health service from an unqualified or incompetent individual. Like in other countries where genetic counseling is well established and statutory regulation systems are not yet available or in place, the profession in Australasia recognized this gap and continues to advocate and campaign for statutory regulation to ensure the highest level of protection for both the public and regulated genetic counselors (Ormond et al., 2018).

\section{Inclusivity}

Genetic counselors are becoming more autonomous in their work, as roles outside of tertiary or university public hospitals are becoming increasingly abundant. Genetic counseling roles are necessarily evolving, and will almost certainly involve the ongoing development of collaborative working relationships with specialists across diverse disciplines, and internationally (Stoll et al., 2018).

This review examined regulation of the genetic counseling profession in Australia exclusively in the clinical context. Historically, HGSA Board Certification was developed and solely based on assessing competency for genetic counselors practicing clinically. As the profession has developed and expanded into other roles, it became apparent that the process of certification is not inclusive of current and emerging roles (including management, administration, education, academia, industry, research, advisory and policy roles).

The working group felt it was best to focus the regulation framework on this model, with the clear intent to develop a more inclusive and expansive framework over time. Further research into genetic counselors working in other settings including academia or education, research, and policy, would be necessary to examine the possibility for 
formal regulation in all genetic counseling roles. Given the diverse skills held by the profession, it is imperative that the benefits of regulation are inclusive of genetic counselors in these roles.

Moving forward, it is indisputable that the profession will continue to evolve internationally (Stoll et al., 2018). The development of the profession in one country continues to influence the experience of genetic counselors in other countries therefore ongoing international collaboration is imperative to support ongoing professionalization in established countries, as well as assisting the establishment of services in other countries (Yashar \& Peterson, 2013).

\section{CONCLUSION}

As a result of the increasing need for a mechanism to protect both the public and the professional from substandard services, the genetic counseling profession in Australasia explored and pursued various regulatory frameworks. Self regulation was sought and achieved under the NASRHP, which subsequently supports the integrity and credibility of health services and of Australasian genetic counselors as allied health professionals, and protects the public from harm. Professional regulation addresses other challenges faced by the profession in Australasia and internationally, including but not limited to; access to reimbursement for services, addressing workforce shortages, and evolving healthcare systems to meet the increasing demand for genetic counseling. A fundamental limitation of self-regulation, however, is the lack of statutory title protection. Further work is underway to determine and establish pathways to afford greater protection of the title 'genetic counselor' in Australasia.

Although one genetic counseling model does not fit all countries, most, including Australasia, recognize formalizing regulation as a pivotal step in the development of 
the genetic counseling profession (Ormond et al., 2018). The general public expect, and deserve, a high standard of genetic counseling given the dramatic advances in technology and in our knowledge and understanding of the natural history of genetic disorders. With the increasing profile of the profession and the role of genetic testing in modern medicine, it is vital that we continue to protect confidence in safety, eliminate potential risks and provide a high quality, evidence-based service to clients.

\section{Author contributions}

C.H. and M.A.Y drafted the manuscript. C.H., C.G., A.M., I.M., A.P., C.S., H.S., J.B., K.E.R., R.W., M.M., M.A.Y revised the manuscript critically for important intellectual content; approved the final version for publication and agree to be accountable for all aspects of the work.

\section{Acknowledgements}

The authors would like to acknowledge the members of the HGSA Professional Issues for Genetic Counsellors Working Party; Jennifer Berkman, Chriss Bull (Project Manager), Clara Gaff, Cass Hoskins Ivan Maccoccia, Alison McEwen, Michael Millward, Amy Pearn, Marian Rawlins, Kate Riley, Carolyn Shalhoub, Hayley Silvemini, Rachel Williams, Mary-Anne Young (Chair), and the members of the HGSA Implementation Committee for Genetic Counselling Regulation: Michelle de Silva, Camron Ebzery, Lara Fitzgerald, Cass Hoskins, Sarah Leighton, Kathleen LeMarquand, Alison McEwen, Michael Millward, Amy Pearn (Chair), Carolyn Shalhoub, Rachel Williams, Laura Yeates, Mary-Anne Young.

\section{Conflict of interest:}


C.H., C.G., A.M., I.M., A.P., C.S., H.S., J.B., K.E.R., R.W., M.M., M.A.Y declare that they have no conflict of interest.

A project officer for the HGSA Professional Issues for Genetic Counsellors Working Party was funded through numerous sources including the HGSA, Australian Genomics Health Alliance, Melbourne Genomics Health Alliance, and AstraZeneca.

\section{Compliance with Ethical Standards:}

No human or non-human animal studies were carried out by the authors for this article.

\section{Data Availability Statement}

Data sharing is not applicable to this article as no new data were collected or analyzed in this study. 


\begin{tabular}{|c|c|c|c|c|}
\hline Region & $\begin{array}{l}\text { Country/ } \\
\text { Region }\end{array}$ & $\begin{array}{l}\text { Internal Self } \\
\text { Regulation by } \\
\text { Professional } \\
\text { Association }\end{array}$ & $\begin{array}{l}\text { Self Regulation by } \\
\text { National } \\
\text { recognition }\end{array}$ & $\begin{array}{l}\text { Statutory } \\
\text { Regulation }\end{array}$ \\
\hline Africa & $\begin{array}{l}\text { South } \\
\text { Africa }\end{array}$ & $\begin{array}{l}\text { Genetic } \\
\text { Counselling South } \\
\text { Africa (GCSA) self } \\
\text { regulates the } \\
\text { training and } \\
\text { registration of } \\
\text { genetic counselors }\end{array}$ & Not Applicable & $\begin{array}{l}\text { Health Professions } \\
\text { Council of South } \\
\text { Africa (HPCSA) } \\
\text { regulate the } \\
\text { genetic counseling } \\
\text { profession }\end{array}$ \\
\hline Asia & & $\begin{array}{l}\text { The major } \\
\text { professional } \\
\text { organisation is the } \\
\text { Professional } \\
\text { Society of Genetic } \\
\text { Counselors in Asia } \\
\text { (PSGCA) } \\
\text { Some countries } \\
\text { have a } \\
\text { professional } \\
\text { society to self } \\
\text { regulate } \\
\text { professionals } \\
\text { within their country } \\
\text { (e.g. genetic } \\
\text { counselors in } \\
\text { Japan achieve } \\
\text { certification with } \\
\text { the Japanese } \\
\text { Society of Genetic } \\
\text { Counseling) }\end{array}$ & Not Applicable & None \\
\hline Europe & & $\begin{array}{l}\text { Genetic Nurse and } \\
\text { Counsellor } \\
\text { Professional } \\
\text { Branch of the } \\
\text { European Board of } \\
\text { Medical Genetics } \\
\text { (EBMG) offers }\end{array}$ & Not Applicable & Country specific \\
\hline
\end{tabular}




\begin{tabular}{|c|c|c|c|c|}
\hline & & $\begin{array}{l}\text { registration within } \\
\text { the European } \\
\text { Union (EU) }\end{array}$ & & \\
\hline & $\begin{array}{l}\text { United } \\
\text { Kingdom }\end{array}$ & $\begin{array}{l}\text { Genetic Counselor } \\
\text { Registration Board } \\
\text { (GCRB) offers } \\
\text { registration to } \\
\text { appropriately } \\
\text { qualified and } \\
\text { trained genetic } \\
\text { counselors }\end{array}$ & Not Applicable & $\begin{array}{l}\text { Graduates of the } \\
\text { three year Scientist } \\
\text { Training } \\
\text { Programme (STP) } \\
\text { are regulated by } \\
\text { the Health Care } \\
\text { Professions } \\
\text { Council } \\
\text { Continue to } \\
\text { campaign for } \\
\text { universal statutory } \\
\text { regulation }\end{array}$ \\
\hline \multirow[t]{2}{*}{$\begin{array}{l}\text { North } \\
\text { America }\end{array}$} & Canada & $\begin{array}{l}\text { Canadian } \\
\text { Association of } \\
\text { Genetic } \\
\text { Counseling } \\
\text { (CAGC) regulate } \\
\text { Canadians through } \\
\text { CCGC Certification } \\
\text { of appropriately } \\
\text { qualified and } \\
\text { trained genetic } \\
\text { counselors }\end{array}$ & Not Applicable & None \\
\hline & $\begin{array}{l}\text { United } \\
\text { States of } \\
\text { America }\end{array}$ & $\begin{array}{l}\text { American Board of } \\
\text { Genetic } \\
\text { Counseling } \\
\text { (ABGC) award } \\
\text { CGC Board } \\
\text { certification to } \\
\text { appropriately } \\
\text { qualified and } \\
\text { trained genetic } \\
\text { counselors }\end{array}$ & Not Applicable & $\begin{array}{l}\text { State by state. } \\
\text { Termed licensure } \\
\text { Currently in place } \\
\text { for }>20 \text { states }\end{array}$ \\
\hline
\end{tabular}




\begin{tabular}{|c|c|c|c|c|}
\hline Oceania & Australia & $\begin{array}{l}\text { Human Genetics } \\
\text { Society of } \\
\text { Australasia } \\
\text { (HGSA) Board of } \\
\text { Censors in Genetic } \\
\text { Counseling awards } \\
\text { certification to } \\
\text { appropriately } \\
\text { qualified and } \\
\text { trained genetic } \\
\text { counselors }\end{array}$ & $\begin{array}{l}\text { Membership of } \\
\text { The National } \\
\text { Alliance of Self- } \\
\text { Regulating Health } \\
\text { Professions } \\
\text { (NASRHP) } \\
\text { (national peak } \\
\text { body representing } \\
\text { self regulated } \\
\text { health } \\
\text { professionals in } \\
\text { Australia, } \\
\text { supported by the } \\
\text { Australian } \\
\text { Department of } \\
\text { Health } \\
\text { Aligned with } \\
\text { National Code of } \\
\text { Conduct }\end{array}$ & None \\
\hline & $\begin{array}{l}\text { New } \\
\text { Zealand }\end{array}$ & $\begin{array}{l}\text { HGSA Board of } \\
\text { Censors in Genetic } \\
\text { Counseling awards } \\
\text { certification to } \\
\text { appropriately } \\
\text { qualified and } \\
\text { trained genetic } \\
\text { counselors }\end{array}$ & Not Applicable & None \\
\hline
\end{tabular}

Table 1: The status of self- and statutory regulation of genetic counselors in select countries. The terms registration and certification are used in the table according to the terminology applied by the relevant professional association for the professional credential for genetic counselors in that region. Data sourced from Abacan et al. (2019). 


\begin{tabular}{|c|c|}
\hline Standard & New/Reviewed/Changes \\
\hline Scope of practice & $\begin{array}{l}\text { New policy developed with consultation from } \\
\text { membership. }\end{array}$ \\
\hline Code of Ethics & $\begin{array}{l}\text { Existing policy reviewed and updated with consultation } \\
\text { from membership. }\end{array}$ \\
\hline Complaints procedure & $\begin{array}{l}\text { New policy and procedure developed. } \\
\text { Professional Concerns and Complaints Committee } \\
\text { formed. }\end{array}$ \\
\hline Competency standards & $\begin{array}{l}\text { Existing policy reviewed and updated with consultation } \\
\text { from/socialization with membership. }\end{array}$ \\
\hline Course Accreditation & $\begin{array}{l}\text { Existing policy reviewed and updated with consultation } \\
\text { from/socialization with membership. }\end{array}$ \\
\hline $\begin{array}{l}\text { Continuing professional } \\
\text { development }\end{array}$ & $\begin{array}{l}\text { Existing policy reviewed and updated with consultation } \\
\text { from/socialization with membership. Extracted from } \\
\text { certification guidelines. }\end{array}$ \\
\hline $\begin{array}{l}\text { English language } \\
\text { requirements }\end{array}$ & New policy developed. \\
\hline Mandatory declarations & $\begin{array}{l}\text { New policy developed with consultation from } \\
\text { membership. }\end{array}$ \\
\hline $\begin{array}{l}\text { Professional indemnity } \\
\text { insurance }\end{array}$ & New policy developed. \\
\hline
\end{tabular}




\begin{tabular}{|l|l|}
$\begin{array}{l}\text { Practitioner Certification } \\
\text { Requirements }\end{array}$ & $\begin{array}{l}\text { Existing policy reviewed and updated and socialized with } \\
\text { membership. }\end{array}$ \\
\hline $\begin{array}{l}\text { Recency and Resumption of } \\
\text { Practice Requirements }\end{array}$ & $\begin{array}{l}\text { New policy and procedure developed in line with } \\
\text { previous certification guidelines. }\end{array}$ \\
\hline
\end{tabular}

Table 2: The 11 standards set by NASRHP demonstrating the HGSA policies that were reviewed and those newly developed to meet the standards. 


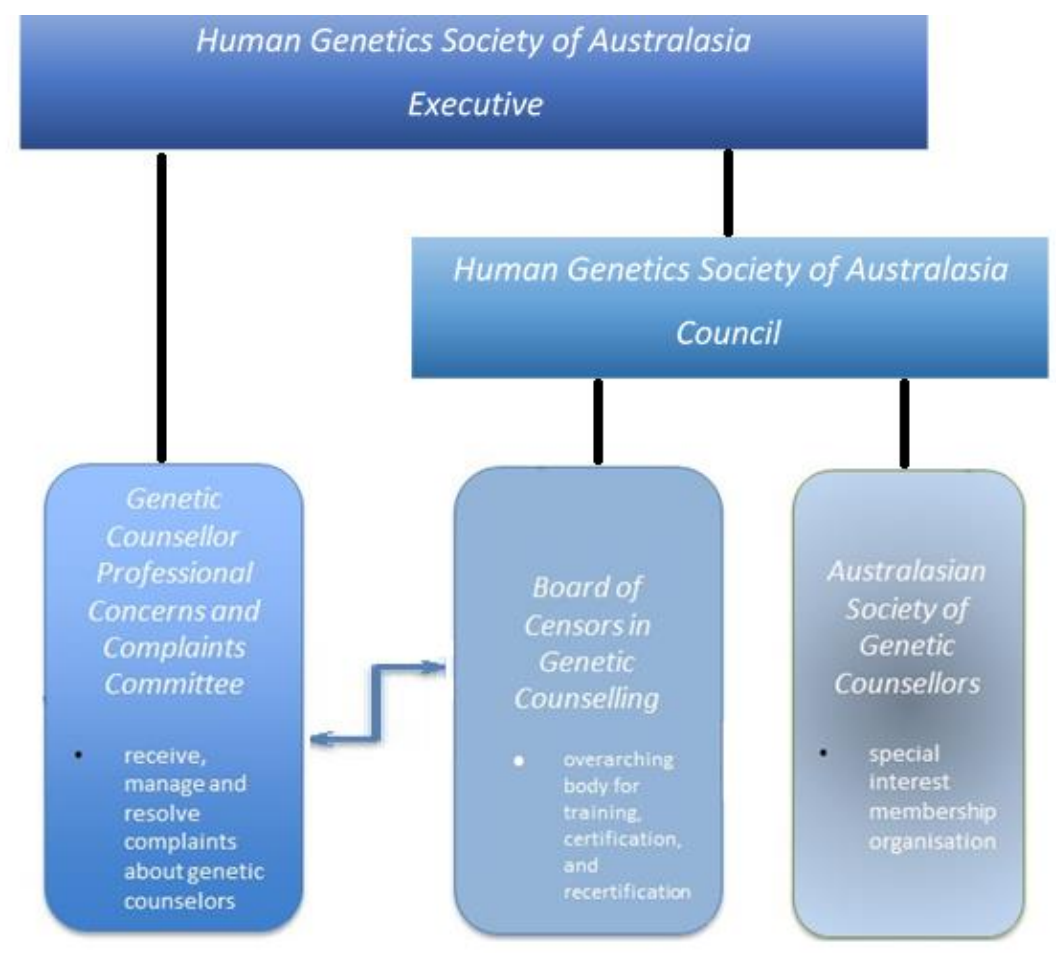

Figure 1: Graphic depicting new organizational structure under HGSA. The preexisting structure was modified to include a newly established committee, the Genetic Counsellor Professional Concerns and Complaints Committee, who report to the HGSA Executive. In the new organizational structure the ASGC remains completely separate from the Board of Censors in Genetic Counselling and the Genetic Counsellor Professional Concerns and Complaints Committee as it is a special interest group for HGSA genetic counselors.

bilateral communication fostered through cross representation and formal reporting by cross representatives.

Reporting lines from the committee to the HGSA 


\section{References}

Abacan, M., Alsubaie, L., Barlow-Stewart, K., Caanen, B., Cordier, C., Courtney, E., Davoine, E., Edwards, J., Elackatt, N. J., \& Gardiner, K. (2018). The global state of the genetic counseling profession. European Journal of Human Genetics, 27(2), 183197.

AGNC Committee (2019) Career Structure for Genetic Counsellors and Support Roles. Retrieved from www.agnc.org.uk.

Allied Health Profession Australia (2012). Harnessing self-regulation to support safety and quality in healthcare delivery: A comprehensive model for regulating all health practitioners. Retrieved from https://www.aopa.org.au.

Australian Health Ministers' Advisory Council (2014). A National Code of Conduct for health care workers. Retrieved from https://www.coaghealthcouncil.gov.au.

Australian Law Reform Commission, \& Australian Health Ethics Committee (2003). Essentially yours: the protection of human genetic information in Australia. ALRC Report, 96. Retrieved from https://www.alrc.gov.au/.

Barlow-Stewart, K., Dunlop, K., Fleischer, R., Shalhoub, C., \& Williams R. (2015). The NSW genetic counselling workforce: Background information paper: An evidence check rapid review brokered by the Sax Institute for the Centre for the NSW Ministry of Health, May 2015. Retrieved from www.saxinstitute.org.au

Baty, B. J. (2018, March). Genetic counseling: Growth of the profession and the professional. In American Journal of Medical Genetics Part C: Seminars in Medical Genetics (Vol. 178, No. 1, pp. 54-62). 
Braithwaite, J., Healy, J., \& Dwan, K. (2005). The governance of health safety and quality. Canberra: Commonwealth of Australia.

CareerCast (2018). The 2018 Jobs Rated Report. Retrieved from https://www.careercast.com/jobs-rated/2018-jobs-rated-report

Carlton, A.-L. (2005). National models for regulation of the health professions. Law Context: A Socio-Legal J., 23, 21.

Cohen, S. A., Tucker, M. E., \& Delk, P. (2017). Genetic counselor workforce issues: a survey of genetic counselors licensed in the State of Indiana. Journal of Genetic Counseling, 26(3), 567-575.

Collis, S., Gaff, C., Wake, S., \& McEwen, A. (2018). Genetic counsellors and private practice: professional turbulence and common values. Journal of Genetic Counseling, 27(4), 782-791.

Cordier, C., Lambert, D., Voelckel, M.-A., Hosterey-Ugander, U., \& Skirton, H. (2012). A profile of the genetic counsellor and genetic nurse profession in European countries. Journal of community genetics, 3(1), 19-24.

Department of Health (2011). Enabling excellence, autonomy and accountability for health care workers, social workers and social care workers. Retrieved from http://www.dh.gov.uk

Edwards, J. G. (2010). A transnational approach: a commentary on lost in translation: limitations of a universal approach in genetic counseling. Journal of Genetic Counseling, 19(1), 7-8. 
Edwards, J. G. (2013). The transnational alliance for genetic counseling: promoting international communication and collaboration. Journal of Genetic Counseling, 22(6), 688-689.

Genetic Counselling Registration Board (2020). New Applicant Guidelines 2020.

Retrieved from https://www.gcrb.org.uk/.

Human Genetics Society of Australasia (2016). Guidelines for Training and Certification in Genetic Counselling. Retrieved from https://www.hgsa.org.au/.

Human Genetics Society of Australasia (2019). Continuing Professional Development for Genetic Counsellors. Retrieved from https://www.hgsa.org.au/.

McEwen, A. R., Young, M. A., \& Wake, S. A. (2013). Genetic counseling training and certification in Australasia. Journal of Genetic Counseling, 22(6), 875-884.

National Society of Genetic Counselors (2019). H.R. 3235 the "Access to Genetic Counselor Services Act". Retrieved from https://www.nsgc.org/.

Nisselle, A., Macciocca, I., McKenzie, F., Vuong, H., Dunlop, K., McClaren, B., Metcalfe, S., Gaff, C., Workforce, A. G., \& Group, E. W. (2019). Readiness of clinical genetic healthcare professionals to provide genomic medicine: An Australian census. Journal of Genetic Counseling, 28(2), 367-377.

Ormond, K. E., Laurino, M. Y., Barlow- Stewart, K., Wessels, T. M., Macaulay, S., Austin, J., \& Middleton, A. (2018). Genetic counseling globally: Where are we now?. In American Journal of Medical Genetics Part C: Seminars in Medical Genetics (Vol. 178, No. 1, pp. 98-107). 
Radford, C., Prince, A., Lewis, K., \& Pal, T. (2014). Factors which impact the delivery of genetic risk assessment services focused on inherited cancer genomics: expanding the role and reach of certified genetics professionals. Journal of Genetic Counseling, 23(4), 522-530.

Sahhar, M. A., Young, M.-A., Sheffield, L. J., \& Aitken, M. (2005). Educating genetic counselors in Australia: developing an international perspective. Journal of Genetic Counseling, 14(4), 283-294.

Sane, V., Humphreys, L., \& Peterson, M. (2015). Are Australasian genetic counselors interested in private practice at the primary care level of health service? Journal of Genetic Counseling, 24(5), 783-796.

Selznick, P. (1985). Focusing organizational research on regulation. Regulatory policy and the social sciences, 1, 363-367.

Skirton, H., Cordier, C., Lambert, D., Ugander, U. H., Voelckel, M.-A., \& O'Connor, A. (2013). A study of the practice of individual genetic counsellors and genetic nurses in Europe. Journal of community genetics, 4(1), 69-75.

Skirton, H., Kerzin-Storrar, L., Barnes, C., Hall, G., Longmuir, M., Patch, C., Scott, G., \& Walford-Moore, J. (2013). Building the genetic counsellor profession in the United Kingdom: two decades of growth and development. Journal of Genetic Counseling, 22(6), 902-906.

Stoll, K., Kubendran, S., \& Cohen, S. A. (2018). The past, present and future of service delivery in genetic counseling: keeping up in the era of precision medicine. In American Journal of Medical Genetics Part C: Seminars in Medical Genetics (Vol. 178, No. 1, pp. 24-37). 
Vlasic, K. (2016, November 22). Former clients of Cairns beautician Suzannah Dacre speak out. Cairns Post. Retrieved from https://www.cairnspost.com.au/ Yashar, B. M., \& Peterson, M. (2013). Introduction to the special issue on genetic counseling: a global perspective. Journal of Genetic Counseling, 22(6), 685-687. 